\title{
Growth and heterogeneity of human capital: effects of the expansion of higher education on the income increase in Brazilian municipalities
}

Leonardo Andrade Rocha, Napiê Galvê Araújo Silva, Carlos Alano Soares de Almeida, Denison Murilo de Oliveira and Kaio César Fernandes

\section{Abstract}

This study analyses the effects of the expansion of the highly skilled labour force (higher education) on the per capita income increase in Brazilian municipalities. The results show that a larger highly educated labour force translates into stronger growth in the most developed municipalities with fewer opportunity costs, measured by wage differences. The reduction of regional inequalities fostered by the expansion of higher education over the past 15 years will become sustainable if the increase in the skill supply is accompanied by a rise in demand, so the opportunity costs between factors are reduced and the skill premium grows.

\section{Keywords}

Human resources, labour force, skilled workers, municipal government, income, regional inequalities, economic growth, Brazil

JEL classification

E24, O43, Q55, R11

\section{Authors}

Leonardo Andrade Rocha holds a doctorate in economic development and is a lecturer at the Centre for Applied Social and Human Sciences (CCSAH) of Universidad Federal Rural do Semi-Árido (UFERSA), Brazil. Email: leonardo.rocha@ufersa.edu.br. Napiê Galvê Araújo Silva holds a doctorate in social sciences and is a lecturer at the Centre for Applied Social and Human Sciences (CCSAH) at Universidad Federal Rural do Semi-Árido (UFERSA), Brazil. Email: pie@ufersa.edu.br.

Carlos Alano Soares de Almeida holds a doctorate in administration and is a lecturer at the Centre for Applied Social and Human Sciences (CCSAH) at Universidad Federal Rural do Semi-Árido (UFERSA), Brazil. Email: alano@ufersa.edu.br.

Denison Murilo de Oliveira holds a doctorate in administration and is a lecturer at the Centre for Applied Social and Human Sciences (CCSAH) at Universidad Federal Rural do Semi-Árido (UFERSA), Brazil. Email: denison@ufersa.edu.br.

Kaio César Fernandes holds a doctorate in social sciences and is a lecturer at the Centre for Applied Social and Human Sciences (CCSAH) at Universidad Federal Rural do Semi-Árido (UFERSA), Brazil. Email: kaio@ufersa.edu.br. 


\section{Introduction}

The importance of human capital for development and the reduction of economic inequalities has been highlighted in numerous studies (Barro, 2001; Barro and Sala-i-Martin, 1992; Becker and Woessmann, 2009; Becker, Hornung and Woessmann, 2011; Benhabib and Spiegel, 1994). It derives from the need for the knowledge acquired by individuals as the economy develops. Knowledge is important both to absorb existing production techniques and to create a new generation of technologies (Benhabib and Spiegel, 2005). Human capital accumulation is historical and has been associated with significant economic divergence in the world (Acemoglu, Gallego and Robinson, 2014).

While these studies have described the importance of human capital in development, some recent research has outlined the heterogeneous nature of this capital (Vandenbussche, Aghion and Meghir, 2006; Ang, Madsen and Islam, 2011; Ott and Soretz, 2011; Basu and Mehra, 2014; Madsen, 2014). Different types of human capital complement the prevailing technological pattern of an economy (Caselli and Coleman, 2006), and are allocated to different activities so economic divergences may be related to differences in human capital composition across economies (Basu and Mehra, 2014).

In Brazil, higher education has expanded significantly over the past 15 years, giving rise to a skilled labour force to meet demand requirements amid the country's ongoing economic transformations. These changes were driven internally, through policies to reduce regional inequalities, and externally, owing to increasing international competition (Mancebo, Vale and Martins, 2015).

According to data from the Higher Education Census (INEP, 2016), registration in higher education institutions in Brazil increased from 2,694,245 in 2000 to 8,027,297 in 2015. ${ }^{1}$ This represents growth of approximately $198 \%$ in that period, which reflects an important strategy of the national education policy.

However, that increase did not always seek to match the growth in the supply of skilled labour with demand. This point is reflected in recent research, especially Cury (2014), Mancebo, Vale and Martins (2015), Lima (2012) and Costa, Costa and Barbosa (2013). According to Cury (2014), there have been major changes in Brazil's higher education system in the last 20 years, particularly its expansion through "partnership" between public and private institutions. However, this expansion has been driven mainly by major mechanisms of financialization and creation of oligopolies within the sector, which regulated part of the process and compromised its quality considerably. The private sector played a greater role in the expansion than the public sector (Mancebo, Vale and Martins, 2015), driving significant transfers of Brazil's public resources over the past few years (Lima, 2012; Costa, Costa and Barbosa, 2013). This process also brought to light some social aspects regarding access to new opportunities as a result of higher education expansion, which ensured greater equity in terms of opportunities and more equality in access to the labour market, serving as a key element of social integration (Felicetti, Cabrera and Costa-Morosini, 2014, p. 36).

This is relevant to the macroeconomic scenario, as the policy aims to obtain the maximum well-being of society through the allocation of limited resources. From a budgetary perspective, economic policy planning in every country involves decisions targeting the efficient allocation of resources in order to bring social returns closer into line with private returns.

As in the works of Vandenbussche, Aghion and Meghir (2006), Aghion (2008) and Aghion and others (2009), this study includes a Schumpeterian growth model in which productivity growth is influenced by two important types of activity: (i) imitation, based on the activity of low-skilled workers implementing existing technologies transferred from the technological frontier; and (ii) innovation, which involves the recruitment of highly skilled labour assigned to research departments. The equilibrium conditions of the innovative business show that the weight of demand for skilled and unskilled labour differs depending on the proximity to the technological frontier, which determines the skill premium and the rate of technological progress.

1 See [online] http://portal.inep.gov.br/web/guest/sinopses-estatisticas-da-educacao-superior. 
Unlike other works, this study uses wage differences to measure the effect of the distance from the frontier, as this variable directly affects factor allocation incentives and is conditioned by fluctuations in proximity to the frontier. In labour market intervention policies, income monitoring becomes more intuitive and therefore more consistent in measuring the regional reality of each municipality.

Using data from the Atlas of Human Development in Brazil (UNDP/IPEA/FJP, 2013) based on the smallest political and administrative dimension, we estimated a linear regression model linking the skilled labour and the per capita GDP of municipalities. On the basis of the controlled model and the generalized method of moments, estimates indicate that the increase in workers with higher education translates into stronger growth in the most developed municipalities with fewer opportunity costs, measured by wage differences.

The debate about the composition of human capital and its effects on economic growth is still recent, so only a few internal and regional studies have been carried out. These include the contributions from Zhang and Zhuang (2011), Gennaioli and others (2013) and Korpi and Clark (2015).

\section{Economic environment}

Based on Aghion and Howitt (1998; 2009), the model consists of an economy with a finite number of sectors, each composed of intermediary business owners and a population of workers who offer their labour in a competitive market. The workers are endowed with heterogeneous human capital resources so that, at the aggregate level, the economy is divided into $S$ units of highly skilled labour and $U$ units of low-skilled labour, offered exogenously and at a constant rate over time. With a competitive market and elastically defined labour supply, we have $(s=\widetilde{S}, u=\widetilde{U}) \epsilon \mathfrak{R}_{+}^{2}$, where $\widetilde{S}$ and $\widetilde{U}$ correspond, respectively, to the equilibrium levels of skilled and unskilled labour in the labour market.

The companies adopt strategies of imitation (implementing the innovations of the most advanced companies or sectors) and of innovation. Each business owner decides to use a balanced combination of the two strategies, with a view to obtaining the benefits of the temporary monopoly of the sector. The decision to adopt more innovative or imitative practices depends on the potential distance from sector leaders (companies with benchmark technology).

Time is discrete (not continuous) and the final economic output is obtained using a continuous flow of intermediate inputs in accordance with the Cobb-Douglas production function:

$$
Y_{t}=\int_{0}^{1} A_{t}(i)^{1-\alpha} x_{t}(i)^{\alpha} d i \therefore \alpha \in(0,1)
$$

According to equation (1), $x_{t}(i)$ corresponds to the flow of intermediate inputs of sector $i$ in time $t$. The productivity of the sector is given by the technology parameter $A_{t}(i)$, which is defined by the lagged level $A_{t-1}(i)$ plus a "strategic sector component". The definition of this component will be addressed in the next section. The intermediate input sector is monopolized by the leading company, which benefits from the monopoly for a short period of time.

Assuming that the final output sector is competitive, each producer of intermediate inputs faces an inverse demand curve that defines the price of the intermediate input:

$$
p_{t}(i)=\frac{\partial Y_{t}}{\partial x_{t}(i)}=\alpha A_{t}(i)^{1-\alpha} x_{t}(i)^{\alpha-1}
$$

In each intermediate sector, only one intermediate producer can produce output $i$ with the productivity of sector $A_{t}(i)$ using the final output as capital. This process will be carried out by means of a one-for-one technology, following the specificity $A_{t}(i): \mathfrak{I} \rightarrow \Omega \therefore Y_{t} \in \mathfrak{I} ; y_{t}(i) \in \Omega$. 
The monopolist of sector $i$ chooses $x_{t}(i)$, which solves the maximization problem:

$$
\max _{x_{t}(i)}\left\{p_{t}(i) x_{t}(i)-x_{t}(i)\right\}
$$

Solving the maximization problem (3) generates an equilibrium demand function:

$$
\widehat{X}_{t}(i)=\alpha \frac{2}{1-\alpha} A_{t}(i)
$$

By replacing (4) in (3), we obtain the equilibrium benefits of the sector monopolist:

$$
\widehat{\pi}_{t}(i)=\left(p_{t}(i)-1\right) \widehat{x}_{t}(i)=\pi A_{t}(i) ; \pi \equiv\left(\frac{1-\alpha}{\alpha}\right) \alpha \frac{2}{1-\alpha}
$$

The sources of productivity growth and their link to the technological frontier are defined below.

\section{Sources of productivity growth}

The dynamics of technology in sector $i$ can be captured by a positive and growing function, $\Phi(\cdot)$, in the following arguments:

$$
A_{t}(i)=A_{t-1}(i)+\underbrace{\Phi\left(\bar{A}_{t-1}(i)-A_{t-1}(i), A_{t-1}(i), u_{t}(i), s_{t}(i)\right)}_{\text {STRATEGIC COMPONENT }}
$$

where $\bar{A}_{t-1}(i), A_{t-1}(i), s_{t}(i), u_{t}(i)$ correspond, respectively, to the technological frontier of sector $i$ at the end of period $t-1$, the productivity of sector $i$ at the end of period $t-1$, and the units of skilled and unskilled labour of sector $i$ at the end of period $t$. The function $\Phi(\cdot)$ is linear in the imitation and innovation components and non-linear in human resources. Specifically, we then have:

$$
\left.A_{t}(i)=A_{t-1}(i)+\left[s_{t}(i)^{\Phi}(\gamma-1) A_{t-1}(i)+u_{t}(i)_{\eta}^{\beta}{ }_{\eta} \bar{A}_{t}(i)-A_{t-1}(i)\right)\right]^{\sigma}
$$

where the parameters $\gamma, \eta$ correspond to the innovative and imitative skills adopted by companies in each sector $i$, satisfying the following inequalities: $\gamma>1$ (one step forward) and $\eta \leq 1$ (one step back). The parameter $\sigma$ reflects the elasticity of the strategic component, which for simplicity is assumed to be $\sigma=1$. The technological frontier grows at a constant rate $\bar{g}, \bar{A}_{t}(i)=(1+\bar{g}) \bar{A}_{t-1}(i)$, and the technological stage of each sector is limited to the level of the frontier; thus, $\bar{A}_{t}(i) \leq \bar{A}_{t}(i)$. The parameters $\Phi, \beta$ represent the coefficients of elasticity of each production factor.

\section{The monopolist's decision and equilibrium conditions}

The monopolist business owner decides to invest in hiring skilled and unskilled labour based on their position and the best rate of return on investment. If they are relatively far from the technological frontier, allocating resources to the recruitment of unskilled labour may generate a bigger improvement than hiring skilled labour, i.e., $\Delta u_{t}(i)^{\beta} \eta\left(\bar{A}_{t}(i)-A_{t-1}(i)>\Delta s_{t}(i)^{\Phi}(\gamma-1) A_{t-1}(i)\right.$.

The decision of the monopolist depends on the optimization of the expected benefits and the cost of the investment, in this case represented by the total cost of hiring labour. Thus, the utility function of the monopolist can be expressed as follows:

$$
U_{t}(i)=E(c)-W_{t}
$$

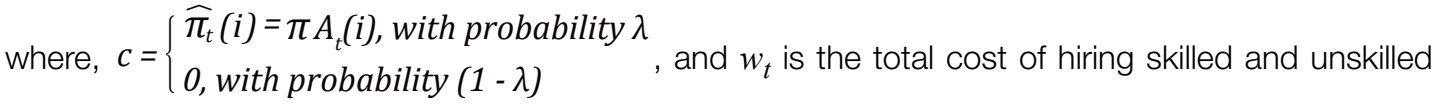


labour. Workers' wages are expressed as $w^{u} A_{t-1}(i)$ (unskilled) and $w^{s} A_{t-1}(i)$ (skilled). ${ }^{2}$ By definition, $w^{i} . \therefore i \in(s, u)$ corresponds to the wage rate. As a result:

$$
W_{t}=w^{u} A_{t-1}(i) u_{t}(i)+w^{s} A_{t-1}(i) s_{t}(i)=\left(w^{u} u_{t}(i)+w^{s} s_{t}(i)\right) A_{t-1}(i)
$$

The problem of maximizing the business owner's profit is defined as:

$$
\max _{u_{t}(i), s_{t}(i)} ; \underset{u_{t}(i), s_{t}(i)}{\max }\left\{\lambda \pi A_{t}-\left(w^{u} u_{t}(i)+w^{s} S_{t}(i)\right) A_{t-1}(i)\right\}
$$

The first-order condition with respect to the arguments $u_{t}(i), s_{t}(i)$ generates the following equilibrium equations:

$$
\begin{gathered}
\frac{\partial U}{\partial s_{t}(i)}=\lambda \pi \Phi s_{t}(i)^{\phi-1}(\gamma-1) A_{t-1}(i)-w^{s} A_{t-1}(i) \equiv 0 \\
\frac{\partial U}{\partial u_{t}(i)}=\lambda \pi \beta u_{t}(i)^{\beta-1} \eta\left(\bar{A}_{t-1}(i)-A_{t-1}(i)\right)-w^{u} A_{t-1}(i) \equiv 0
\end{gathered}
$$

The demand functions of the monopolist in relation to skilled and unskilled labour are obtained by reorganizing equations $U .1$ and $U .2$. These functions are strictly negative with respect to the wage rate and positive with respect to the other function arguments. The demand functions are detailed below:

$$
\begin{gathered}
\widehat{s}_{t}(i)=\left(\frac{\lambda \pi \Phi(\gamma-1)}{w^{s}}\right)^{\frac{1}{1-\phi}} \\
\widehat{u}_{t}(i)=\left(\frac{\lambda \pi \beta \eta\left(d_{t-1}(i)-1\right)}{w^{u}}\right)^{\frac{1}{1-\beta}} \therefore d_{t-1}=\frac{\bar{A}_{t-1}(i)}{A_{t-1}(i)}=\left(a_{t-1}\right)^{-1}
\end{gathered}
$$

where, " $a_{t-1}$ " represents the indicator of proximity to the frontier and its opposite, the distance from the frontier.

With a competitive labour market in equilibrium, the demand for labour is matched by supply, which is given exogenously as $\widehat{u}_{t}(i)=\widetilde{U} ; \widehat{S}_{t}(i)=\widetilde{S}$. The interpretation of equation $\mathrm{E}$. 1 shows that the demand for skilled labour depends positively on the probability of success $\lambda$ of the innovating company, the profit equilibrium parameter $\pi$ and the incremental size of the innovation strategy $(\gamma-1)$.

The second equation E.2 reveals that the business owner's demand for unskilled labour is a positive function of the technological distance $d_{t-1}(i)$ of sector $i$. The low level of training reveals short-term interest focused on imitation strategies. Companies' significant lag leads business owners to assign a proportion of unskilled workers to less innovation-intensive activities. As the sector approaches the frontier, the monopolistic business owner will demand more and more labour focused on research and development (R\&D) activities.

There are also important considerations about demand functions: it is not isolated growth that conditions the business owner's factor demand, but rather growth accompanied by the narrowing of the technological gap between economies. As the economy grows and closes the gap, structural changes "condition" business demand, which in turn has an impact on growth and gives rise to new demand. ${ }^{3}$

2 Wages are proportional to productivity because technological advances increase the returns on the labour involved in activities. In this sense also, $w^{s>>w^{u}}$, showing that the skill premium is higher for the most skilled labour. See Vandenbussche, Aghion and Meghir (2006) and Aghion and others (2009) for more details.

3 According to Dosi, Fagiolo and Roventini (2010), growth as well as demand factors lead to technological changes in the long run. Is the long-term growth just driven by changes in the technological "fundamentals"? Or, can variations in aggregate demand influence future dynamics? And, ultimately, can one identify multiple growth paths whose selection depends on demand and institutional conditions[...]? (Dosi, Fagiolo and Roventini, 2010, p. 1748). 


\section{Skill premium}

According to Acemoglu (1998), the skill premium represents the wage differentials between skilled and unskilled labour that generate opportunity costs among production factors. Thus, a low premium implies high opportunity costs in skilled labour, which can be explained by low pay linked to insufficient demand, resulting from the low level of development prevailing in the economy. As in business theory, the business owner seeks a factor level where marginal cost equals marginal value. The definition of marginal value is associated with the concept of marginal factor productivity, which is proportional to a company's level of technology. Higher productivity levels allow for an increase in the production factor output, increasing its skill premium.

In this study, the skill premium function can be expressed by the relationship between equilibrium spending for each production factor:

$$
w_{t}(i) \equiv \frac{w^{s} A_{t-1}(i) \hat{s}_{t}(i)}{w^{u} A_{t-1}(i) \hat{u}_{t}(i)}=(\lambda \pi)^{\frac{\varphi-\beta}{(1-\varphi)(1-\beta)}} \cdot\left[\frac{(\varphi(\gamma-1))^{\frac{1}{1-\varphi}}}{\left(\beta \eta\left(d_{t-1}(i)-1\right)\right)^{\frac{1}{1-\beta}}}\right] \cdot \frac{\left(w^{u}\right)^{\frac{1}{1-\beta}}}{\left(w^{s}\right)^{\frac{1}{1-\varphi}}}
$$

According to equation W.1, the skill premium is inversely determined by the distance from the frontier. A low level of productivity in the sector means weaker demand for skilled labour, so the output of this factor is reduced and the skill premium decreases. An increase in innovation activities $\gamma$ raises the skill premium, in the same way that an increase in imitation strategies $\eta$ requires a less skilled factor and reduces the skill premium.

In this case, the larger wage differences imply higher costs for the most skilled factor, reducing its contribution to productivity growth. On the contrary, productivity patterns close to the frontier imply a higher output of the factor most responsible for the company's proximity, increasing the skill premium. Therefore, fluctuations in proximity to the frontier lead to fluctuations in the skill premium.

\section{Growth and production factor demand}

Based on the demand functions E.1 and E.2, the rate of technological progress can be reformulated as follows:

$$
\begin{aligned}
& A_{t}(i)=A_{t-1}(i)+s_{t}(i)^{\phi}(\gamma-1) A_{t-1}(i)+u_{t}(i)^{\beta} \eta\left(\bar{A}_{t}(i)-A_{t-1}(i)\right) \sigma=1 \\
& g_{t}(i)=\frac{A_{t}(i)-A_{t-1}(i)}{A_{t-1}(i)}=\hat{s}_{t}(i)^{\Phi}(\gamma-1)+\hat{u}_{t}(i)^{\beta} \eta\left(d_{t-1}(i)-1\right)
\end{aligned}
$$

The rate of technical progress is a function of the demand curves, which establish the equilibrium conditions of the parameters of imitation, innovation and distance from the frontier. By replacing E.1 and $E .2$ in G.1, we obtain:

$$
g_{t}(i)=(\gamma-1)^{\frac{1}{1-\phi}}\left(\frac{\lambda \pi \Phi}{w^{S}}\right)^{\frac{\phi}{1-\Phi}}+\eta^{\frac{1}{1-\beta}}\left(\frac{\lambda \pi \beta}{w^{u}}\right)^{\frac{\beta}{1-\beta}}\left(d_{t-1}(i)-1\right)^{\frac{1}{1-\beta}}
$$

Equation G.2 presents an important conclusion of the study:

- Proposition 1: The sectors furthest from the technological frontier reflect a different demand for resources than the most advanced sectors. In the economies furthest from the frontier there is a deficit in demand for skilled labour that reduces the skill premium and its contribution to productivity growth. In other words, $d_{t-1}(i) \geq 1 \Rightarrow \hat{u}_{t}(i) \geq 0$.

Proposition 1 shows that distance from the frontier directly affects productivity growth, which is determined by the demand for each production factor. This conclusion can be presented through the partial second-order derivative with the growth function. 
- Test: by rewriting equation G.2, we have:

$$
\frac{\partial^{2} g_{t}(i)}{\partial d_{t-1}(i) \partial \eta}=\left(\frac{\beta}{1-\beta}\right)^{2}\left(\frac{\lambda \pi \beta \eta\left(d_{t-1}(i)-1\right.}{w^{u}}\right)^{\frac{\beta}{1-\beta}} \geq 0 \Rightarrow d_{t-1}(i) \geq 1
$$

Equation G.3 shows that the rate of change in technical progress depends positively on the distance from the frontier. If there is a potential lag $d_{t-1}(i)>1$, training through intensive imitation practices and unskilled labour demand can provide viable technological opportunities that reinforce short-term growth. Therefore, a low skill premium is caused by a deficit in skilled labour demand, which limits the contribution to productivity growth.

\section{Empirical methodology}

\section{Definition of the sample and operationalization of the variables}

The data used in this study were taken from the Atlas of Human Development in Brazil (UNDP/IPEAFFJP, 2013), which includes more than 200 indicators of demographics, education, income, work, housing and vulnerability of Brazilian municipalities from the 1991, 2000 and 2010 demographic censuses (IBGE, n/da).

In order to analyse the most recent information, the decision was taken to define the total of 5,565 municipalities based on the year 2010. In addition, some important variables used in the study - such as the average income of employed persons - are only available in this database for $2010 .{ }^{4}$ Given the aim to employ a sample with as much data as possible and without too much loss of generality, the cross section did not imply serious limitations for the data sample, as the 5,565 municipalities selected are sufficient for a suitable inference for the model.

The variables used in the research are described in table 1.

Table 1

Description of the variables used

\begin{tabular}{ll}
\hline Acronym & Definition \\
\hline RDPC & Per capita income \\
\hline RENOCUP & Average income of employed persons aged 18 years and over \\
\hline$P_{\text {SUPER }}$ & Percentage of employed persons aged 18 years and over having completed higher education \\
\hline PRENTRAB & Percentage of labour income \\
\hline$T_{\text {FBSUPER }}$ & Gross attendance rate, higher education \\
\hline$P_{\text {MED }}$ & Percentage of employed persons aged 18 years and over having completed secondary education \\
\hline TRABCC & Percentage of employees aged 18 years and over with an employment contract \\
\hline$P_{\text {TRANSF }}$ & Percentage of persons aged 18 years and over employed in the processing industry \\
\hline REN & Percentage of employed persons aged 18 years and over without income \\
\hline$E_{\text {ANOSESTUD0 }}$ & Expectation of years of study at age 18 \\
\hline$T_{\text {MED18M }}$ & Percentage of the population aged $18-20$ years having completed secondary education \\
\hline$T_{\text {FBMED }}$ & Gross attendance rate, secondary education \\
\hline$T_{\text {SUPER25M }}$ & Percentage of the population aged 25 years and over having completed higher education \\
\hline
\end{tabular}

Source: United Nations Development Programme (UNDP)/Institute of Applied Economic Research (IPEA)/João Pinheiro Foundation (FJP), "Atlas of Human Development in Brazil”, 2013 [online database] http://www.atlasbrasil.org.br/2013/en/consulta/.

\footnotetext{
4 While the highlights of the 2010 data are based on the Atlas of Human Development in Brazil (UNDP/IPEA/FJP, 2013), it should be emphasized that other important databases may guide the continuity of this research: the National Household Sample Survey (PNAD) (IBGE, n/db) and the microdata of the 2010 Population Census (IBGE, n/da). These databases include more detailed information that, in principle, correlates with the data presented in the Atlas.
} 
The next section describes the linear regression model that seeks to analyse the relationships between the variables according to the description of the theoretical model.

\section{Linear regression model}

The set of equations to be estimated consists of:

Reg.1

$$
\begin{aligned}
\log \left(R_{D P P C}\right) & =\alpha+\beta_{1} \cdot P_{\text {SUPER }_{i j}}+\beta_{2} \cdot\left[P_{\text {SUPER }_{i j}} * w_{\text {relat }_{i j}}\right]+\beta_{3} \cdot P_{\text {TRANSF }_{i j}}+\beta_{4} \cdot R E N_{o_{i j}} \\
& +\beta_{5} \cdot E_{\text {ANOSESTUDO }_{i j}}+\beta_{6} \cdot T_{\text {MED18M }_{i j}}+\beta_{7} \cdot T_{\text {FBMED }_{i j}}+\beta_{8} \cdot T_{{\text {SUPER } 25 M_{i j}}} \\
& +\delta_{j} \cdot \varepsilon_{i j}
\end{aligned}
$$

Reg.2

$$
\begin{aligned}
& P_{\text {SUPER }_{i j}}=\alpha^{\prime}+\beta_{1}^{\prime} \text { PRENTRAB }_{i j}+\beta_{2}^{\prime} \cdot T_{\text {FBSUPER }_{i j}}+\beta_{3}^{\prime} \cdot P_{\text {MED }_{i j}}+\beta_{4}^{\prime} \cdot \text { TRABCC }_{i j} \\
& +\gamma \cdot x+\delta_{j}^{\prime}+\varepsilon_{i j}^{\prime}
\end{aligned}
$$

Reg.3

$$
\begin{aligned}
P_{\text {SUPER }_{i j}}{ }^{*} w_{\text {relat }_{i j}} & \alpha^{\prime \prime}+\beta^{\prime \prime}{ }_{1} \operatorname{PRENTRAB}_{i j}+\beta^{\prime \prime}{ }_{2} \cdot T_{\text {FBSUPER }}+\beta^{\prime \prime}{ }_{3} \cdot P_{\text {MED }} \\
& +\beta^{\prime \prime}{ }_{4} \cdot \operatorname{TRABCC_{ij}}+\theta \cdot x+\delta^{\prime \prime}{ }_{j}+\varepsilon^{\prime \prime}{ }_{i j}
\end{aligned}
$$

Equation Reg.1 is the main equation of the study. It analyses the contribution of skilled labour assigned to productive activities, to the extent that the oscillations in relative wages across municipalities capture the opportunity cost among production factors.

These relative wages are represented by the variable " $w_{\text {relat }}$ " which corresponds to the relationship between the average income of employed persons (RENOCUP) of the municipality and the maximum value observed in the corresponding state. Thus, regional differences do not influence the calculation of the relative measure, and the variable ranges between $0 \leq w_{\text {relat }} \leq 1$ for each state. Values close to 1 represent municipalities that are close to the highest average wages within the state, indicating higher earnings in the regional sample and, therefore, relatively lower opportunity costs of labour and vice versa. This relative measure indirectly captures the degree of proximity to the frontier, according to equation W.1. The vector $X$ included in equations Reg.2 and Reg.3 represents the other regressors of equation Reg.1.

The vectors $\delta_{j}, \delta_{j}^{\prime}, \delta_{j}^{\prime \prime}$ represent the set of fixed effects relating to the specific characteristics of each state. These characteristics, duly included in the model, capture different patterns of development, policies, demographics and other aspects that influence the relationships between variables. In this case, their exclusion would imply a serious specification error in the model, which would lead to inconsistencies in parameter estimates (Greene, 2012).

The variables $\varepsilon_{i j}, \varepsilon_{i j}^{\prime}, \varepsilon_{i j}^{\prime \prime}$ represent the measure of error or ignorance and therefore capture the other factors irrelevant to the model.

\section{Estimation method}

Equations Reg.1-3 present an endogeneity relationship that needs to be adequately addressed in the estimation of parameters. Neglecting it implies serious errors in specification and method, which cause biases and inconsistencies in the technique. One of the most popular approaches to solving this methodological problem is the instrumental variables estimator (Galvao and Montes-Rojas, 2015). 
In turn, the method must meet the following validity conditions in order to ensure unbiased and consistent parameter estimates (Hsiao and Zhang, 2015): the instruments (variables exogenous to the model) must be (i) valid, and therefore not correlated with the stochastic disturbance; and (ii) relevant, so that they capture important information on endogenous regressors.

To test the described hypotheses, two important test statistics were implemented to evaluate the suitability of the selected instruments. These statistics are described in table 2.

Table 2

Summary of model test statistics

\begin{tabular}{lll}
\hline Test & \multicolumn{2}{c}{ Summary of statistics } \\
\hline Hansen's J test (Hayashi, 2000) & Null hypothesis $\left(\mathrm{H}_{0}\right)$ & Alternative hypothesis $\left(\mathrm{H}_{\mathrm{a}}\right)$ \\
\cline { 2 - 3 } & Valid instruments not correlated with the error term & Invalid instruments correlated with the error term \\
\hline Kleibergen and Paap (2006) & Null hypothesis $\left(\mathrm{H}_{0}\right)$ & Alternative hypothesis $\left(\mathrm{H}_{\mathrm{a}}\right)$ \\
\cline { 2 - 3 } & $\begin{array}{l}\text { Irrelevant instruments with weak or no correlation } \\
\text { with endogenous regressors }\end{array}$ & $\begin{array}{l}\text { Relevant instruments strongly correlated } \\
\text { with endogenous regressors }\end{array}$ \\
\hline
\end{tabular}

Source: Prepared by the authors.

While the results of the statistics indicate a suitable selection of instruments, the instrumental variables method is subject to the loss of efficiency of the estimates when there are heterogeneity problems in the estimated model. This violation of the statistical hypothesis results in a bias in the estimates in table 2, so they must be corrected to reach a suitable conclusion on the instruments and the outcome of the model (Hayashi, 2000; Baum, Schaffer and Stillman, 2003).

To verify the presence of heteroscedasticity, the model incorporated the Pagan and Hall test (1983) adapted to the instrumental variables method (Baum, Schaffer and Stillman, 2003). Once its presence was detected, the issue was corrected by generating residual series using the states as a group model (cluster). This process leads to efficient estimates, allowing subsequent testing of the suitability of the most reliable and consistent instruments.

Finally, to ensure estimation alternatives and greater precision, the generalized method of moments was applied to the model, in reference to the contributions of Hansen (1982). In the presence of heteroscedasticity, the generalized method of moments reflects efficiency gains in estimates compared to traditional instrumental variables estimators (Baum, Schaffer and Stillman, 2003). These results were also recently shown in Cameron and Trivedi (2005) and Hsiao and Zhang (2015).

Table 3 describes the variables used in the model.

Table 3

Description of variables in the estimation method

\begin{tabular}{lll}
\hline Variables used & Instruments included & Instruments excluded \\
\hline $\mathrm{P}_{\text {SUPER }}$ & $\mathrm{P}_{\text {TRANSF }}$ & PRENTRAB \\
\hline$\left[\mathrm{P}_{\text {SUPER }}{ }^{*} \mathrm{~W}_{\text {relat }}\right]$ & REN & $\mathrm{T}_{\text {FBSUPER }}$ \\
\hline & $\mathrm{E}_{\text {ANOSESTUDO }}$ & TRABCC \\
\hline & $\mathrm{T}_{\text {MED18M }}$ & $\mathrm{P}_{\text {MED }}$ \\
\hline & $\mathrm{T}_{\text {FBMED }}$ & \\
\hline & $\mathrm{T}_{\text {SUPER25M }}$ & \\
\hline
\end{tabular}

Source: Prepared by the authors.

\section{Selection of instruments}

To capture the determinants of human capital stock and labour market differences, some recent studies -especially Philippon and Reshef (2012) and Gennaioli and others (2013) - have pointed out that 
differences in human capital are important sources of regional inequality and persist over time in several regions of the world. Like all capital, it must be accumulated through effort, with output being produced through the skills acquired (Lucas, 2009). In this case, labour income serves as an available resource to finance the expansion of skills, which translates into new sources of asymmetry in wage distribution.

Gennaioli and others (2013) found that wages are relatively higher in the most productive and developed regions and that this difference intensifies the migration effect from the least developed regions. Skilled workers living in the least productive regions are encouraged to migrate because of the high opportunity cost among factors. Thus, the most skilled workers have a bigger incentive to pay the migration cost because the benefits received are much greater. This further expands the pool of skills, increasing the demand for new training courses as a result of local dynamics. The increased demand for new types of skill increases enrolment in training courses, which tends to be relatively higher in the most developed regions. This fosters a reallocation of skills in the labour market, where more weight is given to highly skilled labour than to low-skilled labour (Schiopu, 2015).

Recently, Bastgen and Holzner (2017) showed an important relationship between development, innovation and employment protection. According to the authors, formal employment and its protection by legislation mean that companies keep workers employed even in low productivity periods. As a result, companies increase their innovation initiatives to offset this process. Technological advances offset the decline in productivity and further stimulate training of skilled workers. This process alters local economic activity, generating more development and strengthening the relationship between labour market protection and innovation. Thus, legislation that protects the labour market stimulates innovation and new firm creation, so many countries with strict labour laws tend to encourage and specialize in improving existing products and processes (Acharya, Baghai and Subramanian, 2014; Koeniger, 2005).

\section{Analysis of the results}

\section{Descriptive analysis of the sample}

Table 4 presents the main descriptive statistics of the data sample.

Table 4

Descriptive analysis of the sample

\begin{tabular}{lrrrr}
\hline Variable & Average & Standard deviation & Minimum & Maximum \\
\hline RDPC & 493.61 & 243.27 & 96.25 & 2043.74 \\
\hline RENOCUP & 780.11 & 341.68 & 136.42 & 3177.26 \\
\hline$P_{\text {SUPER }}$ & 7.04 & 3.61 & 0.32 & 37.53 \\
\hline PRENTRAB & 68.48 & 10.80 & 27.43 & 95.24 \\
\hline$T_{\text {FBSUPER }}$ & 19.10 & 10.38 & 0.96 & 76.78 \\
\hline$P_{\text {MED }}$ & 30.42 & 9.84 & 4.16 & 73.65 \\
\hline TRABCC & 30.25 & 18.05 & 0.90 & 83.21 \\
\hline PTRANSF $_{\text {TREN }}$ & 9.61 & 8.92 & 0.00 & 65.11 \\
\hline REN & 13.42 & 11.98 & 0.00 & 73.93 \\
\hline E $_{\text {ANOSESTUDO }}$ & 9.46 & 1.10 & 4.34 & 12.83 \\
\hline$T_{\text {MED18M }}$ & 24.75 & 8.68 & 3.04 & 66.23 \\
\hline$T_{\text {FBMED }}$ & 65.85 & 14.97 & 0.00 & 168.64 \\
\hline$T_{\text {SUPER25M }}$ & 5.50 & 3.26 & 0.28 & 33.68 \\
\hline
\end{tabular}

Source: Prepared by the authors. 
The average per capita income of the municipalities was 493.61 reais, between a minimum value of 96.25 reais and a maximum value of 2,043.74 reais. Considering the income of employed persons, the average value increases to 780.11 reais (a variation corresponding to $58.04 \%$ ), with a minimum of 136.42 reais and a maximum of $3,177.26$ reais.

The average percentage of employed people having completed higher education in the municipalities was around $7 \%$, with a minimum of $0.32 \%$ and a maximum of $37.53 \%$. With regard to labour income, the highest value is $95.24 \%$ (in this municipality, $95.24 \%$ of total income derives from work), while the average corresponds to $68.48 \%$.

The percentage of employed persons having completed secondary education was significantly higher than that of employed persons having completed higher education, at $30.42 \%$. The lowest percentage recorded was approximately $4 \%$, while the highest value was over $70 \%$.

The percentage of workers with an employment contract partly captures the level of formality in the local economy. In defining this share of formality in terms of workers with an employment contract, the public sector is not taken into account. ${ }^{5}$ According to some recent research, especially Mattos (2011 and 2015), public employment accounts for about 10.7\% of employed persons in Brazil (in the broadest sense, which includes direct, indirect and state administration of all kinds). This low percentage will not result in large losses of asymptotic quality for the model, as the instruments will be tested prior to validation (Greene, 2012).

Municipal data show a low proportion of workers with an employment contract, as the average is approximately $30.25 \%$ of employed persons in the reference age group. The maximum percentage is $83.21 \%$, so only $16.79 \%$ of employed workers would not have an employment contract in that municipality.

Another important piece of information concerning the labour market is employment in the processing industry. The average percentage of workers employed in this sector was approximately $9.6 \%$, with a maximum value of $65.11 \%$.

An analysis of the percentage of employed workers without income reveals an average percentage of $13.42 \%$. This variable reflected a minimum value of zero and a maximum value of $73.93 \%$. This indicates that inequality related to the lack of wages prevails in some municipalities in the sample.

An important dimension of municipal development is the expectation of education, which projects the expectation of years of study for future generations. The average expectation was 9.46 years of study, and the maximum value was 12.83 .

The proportion of the population having completed secondary education stood at a low average of $24.75 \%$. In the municipality with the highest value, $66.23 \%$ of the population had completed secondary education. The proportion of the population aged 25 years and over having completed higher education was also relatively low, averaging 5.5\%, with a maximum of 33.68\% (lower than the proportions of employed persons).

Table 5 shows the correlation between the variables used in the model. The variable log(RDPC) reflected a significant correlation with all the selected variables (significant at $1 \%$ ). The strongest correlation with $\log (\mathrm{RDPC})$ corresponded to the variable $\mathrm{REN}_{0}$, which represents the percentage of employed workers without income $(\rho=-0.737)$, followed by the proportion of persons having completed secondary education $(\rho=0.736)$.

Only one variable reflected a weak correlation coefficient, the gross secondary school attendance rate $(\rho=0.271$, although significant at $1 \%)$. All other variables reflected correlation coefficients greater than $\rho=0.50$, showing medium and strong correlations.

\footnotetext{
5 This variable excludes military personnel in the army, navy, aeronautics, military police and the fire brigade, and employees included in the legal regime of civil servants, as well as employers and own-account workers contributing to a public social security agency, as these categories present a different dynamic in the labour market.
} 


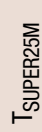

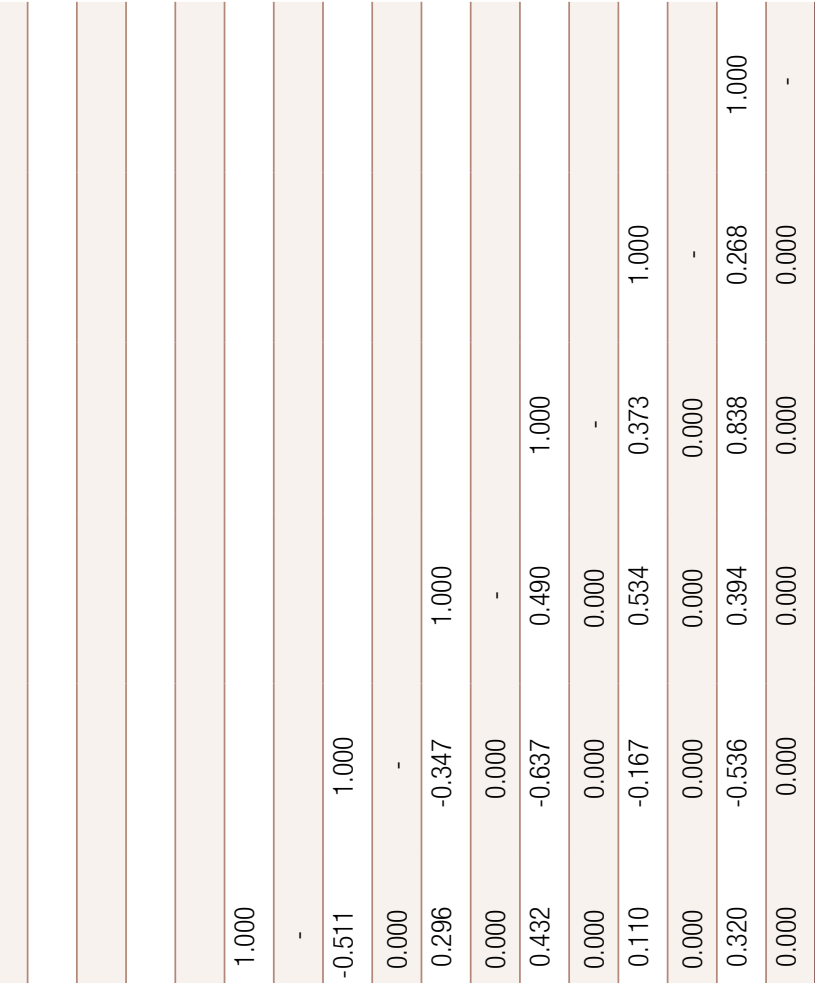

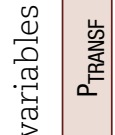

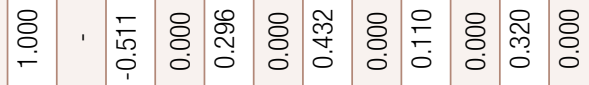

结

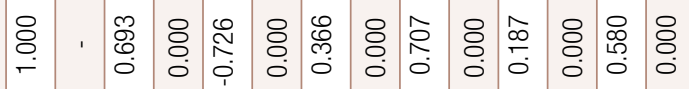

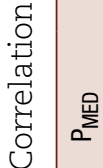

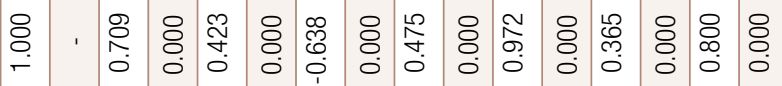

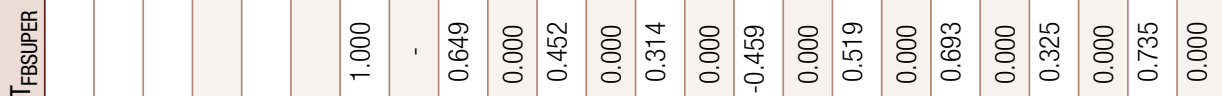

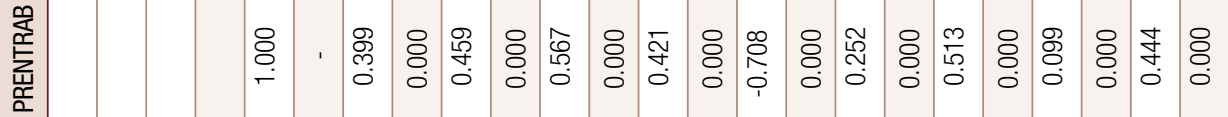

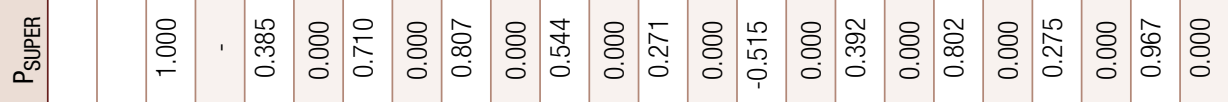

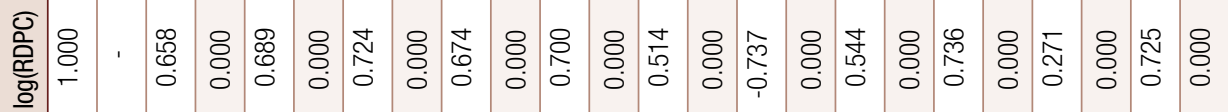

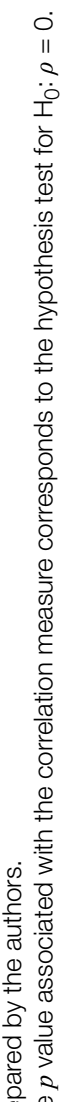

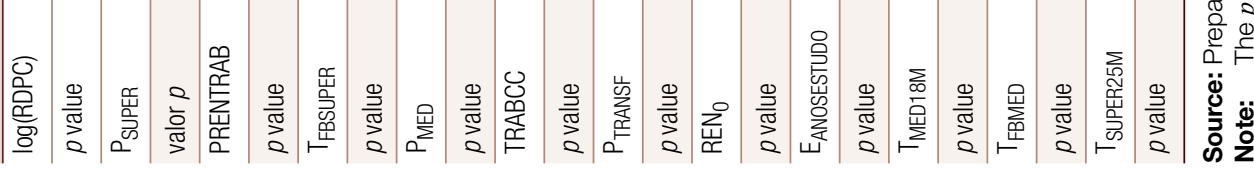




\section{Regression model analysis}

The results of the model estimated according to the ordinary least squares technique, including the fixed effects for each state, are detailed in table 6.

Table 6

Econometric model results

\begin{tabular}{|c|c|c|}
\hline Variables & $\begin{array}{l}\text { (1) } \\
\text { Ordinary least squares } \\
\text { Fixed effects }\end{array}$ & $\begin{array}{c}(2) \\
\text { Ordinary least squares } \\
\text { Fixed effects }\end{array}$ \\
\hline \multirow[t]{2}{*}{$P_{\text {SUPER }}$} & $-0.0252^{\star \star}$ & $-0.0653^{* * *}$ \\
\hline & $(0.00940)$ & $(0.00771)$ \\
\hline \multirow[t]{2}{*}{$\mathrm{P}_{\text {SUPER }}{ }^{*} \mathrm{~W}_{\text {relat }}$} & $0.115^{\star \star \star}$ & $0.0646^{\star \star \star}$ \\
\hline & $(0.0153)$ & $(0.0102)$ \\
\hline \multirow[t]{2}{*}{$\mathrm{P}_{\text {TRANSF }}$} & & $0.00311^{\star \star \star}$ \\
\hline & & $(0.000495)$ \\
\hline \multirow[t]{2}{*}{$\mathrm{REN}_{0}$} & & $-0.00949^{\star \star *}$ \\
\hline & & $(0.00127)$ \\
\hline \multirow[t]{2}{*}{$\mathrm{E}_{\text {ANOSESTUDO }}$} & & $0.0316^{* \star *}$ \\
\hline & & $(0.00573)$ \\
\hline \multirow[t]{2}{*}{$\mathrm{T}_{\text {MED18M }}$} & & $0.00679^{\star \star \star}$ \\
\hline & & $(0.00141)$ \\
\hline \multirow[t]{2}{*}{$\mathrm{T}_{\text {FBMED }}$} & & 0.000383 \\
\hline & & $(0.000407)$ \\
\hline \multirow[t]{2}{*}{$\mathrm{T}_{\text {SUPER25M }}$} & & $0.0603^{\text {***}}$ \\
\hline & & $(0.00797)$ \\
\hline \multirow[t]{2}{*}{ Constant } & $5.477^{\star \star \star}$ & $5.371^{\star \star \star}$ \\
\hline & $(0.0287)$ & $(0.0512)$ \\
\hline Fixed effects & - & - \\
\hline - State & Yes & Yes \\
\hline Heteroscedasticity test & - & - \\
\hline$-\chi^{2}$ & 734.65 & 98.44 \\
\hline - $p$ value & 0.0000 & 0.0000 \\
\hline $\mathrm{R}^{2}$ & 0.846 & 0.906 \\
\hline Adjusted $\mathrm{R}^{2}$ & 0.845 & 0.906 \\
\hline F statistic & 1082.87 & 1573.29 \\
\hline F statistic ( $p$ value) & 0.0000 & 0.0000 \\
\hline
\end{tabular}

Source: Prepared by the authors.

Note: $\quad{ }^{* \star *} p<0.01,{ }^{* \star} p<0.05,{ }^{*} p<0.1$.

Confirmation in heteroscedasticity tests involved recalculating the covariance of parameters following the residual series technique using the states as a group model (clusters).

According to the results detailed in the table, the parameter linked to the proportion of employed persons having completed higher education showed a negative value in both columns (significant at 1\%). The parameter represents semi-elasticity of the variable in the per capita income of municipalities. Thus, excluding the influence of wage differences on the demand for skilled labour, an increase of one unit in the proportion of employed persons contributes to an average reduction of $2.6 \%$ (column (1)) and of $6.7 \%$ (column (2)) $\left[\left(e^{\beta}-1\right)^{\star} 100\right]$. However, this average effect is not consistent with the literature presented, suggesting that the sign linked to the estimated parameter is influenced by wage differences based on the model presented. In this case, the parameter associated with the cross-effect is presented as positive, which indicates that the final effect of the relationship depends on the proximity of the maximum levels of income for each state.

This empirical evidence suggests that the differences between incomes indicate the existence of opportunity costs among factors. Thus, on average, the most developed municipalities provide greater benefits, reducing opportunity costs among the factors (see figure 1). 
Figure 1

Relationship between average income of employed persons and per capita income (In reais)

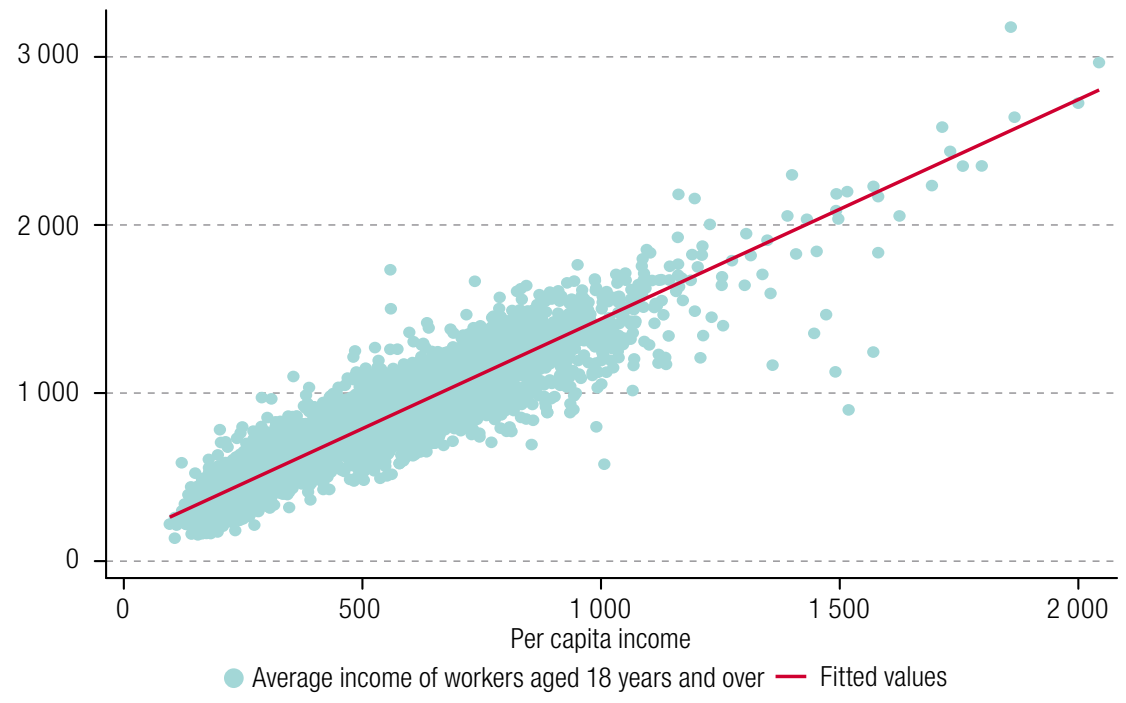

Source: Prepared by the authors.

The parameter corresponding to the percentage of employed persons without income reflected the expected negative sign and was significant at $1 \%$. Thus, on average, an increase of one unit tends to reduce per capita income by $0.95 \%$. The expectation of years of study reflected the expected positive relationship. On average, a further increase in the expectation of years of study contributes to a $3.21 \%$ increase in per capita income.

When comparing the proportion of the population having completed secondary education with that having completed higher education, both parameters showed the expected positive signs and statistical significance (level of 1\%). However, an increase in the proportion of the population having completed secondary education contributes to a rise of approximately $0.68 \%$ in per capita income, compared to an increase of $6.22 \%$ in the case of a rise in the proportion of the population having completed higher education.

Heteroscedasticity tests showed a rejection of the null hypothesis at $1 \%$ homoscedastic variance. The variance-covariance matrix was recalculated so that the standard error estimates would be consistent (efficient parameters). The explanatory power of the model reflected a high value in columns (1) and (2), in addition to adjusted $\mathrm{R}^{2}$ measures close to the explanatory power. The models reflected overall significance based on high $\mathrm{F}$ statistics values and corresponding $p$ values (significant at $1 \%$ ).

Figure 2 shows that the proximity of income to the maximum value in each state increases the impact of highly qualified human capital on the per capita income of the municipalities.

As shown in figure 2, the final effect of highly skilled labour is conditioned by wage differences. The figure shows that the positive effect is estimated based on a difference of 0.22 or $22 \%$. Thus, in municipalities where average income ranges from more than $22 \%$ to the maximum observed in the state, the expansion of the workforce with higher education leads to a positive relationship with the increase in per capita income.

This analysis indicates that the relationship between human capital and its impact on wealth generation reflects heterogeneous results that are not always suitably addressed in the analysis. Some factors relating to different opportunity costs among factors may condition these effects, leading to a bias in the relationship between the variables, which increases as these regional differences become more significant. 
Figure 2

Simulation based on the results of the estimated model

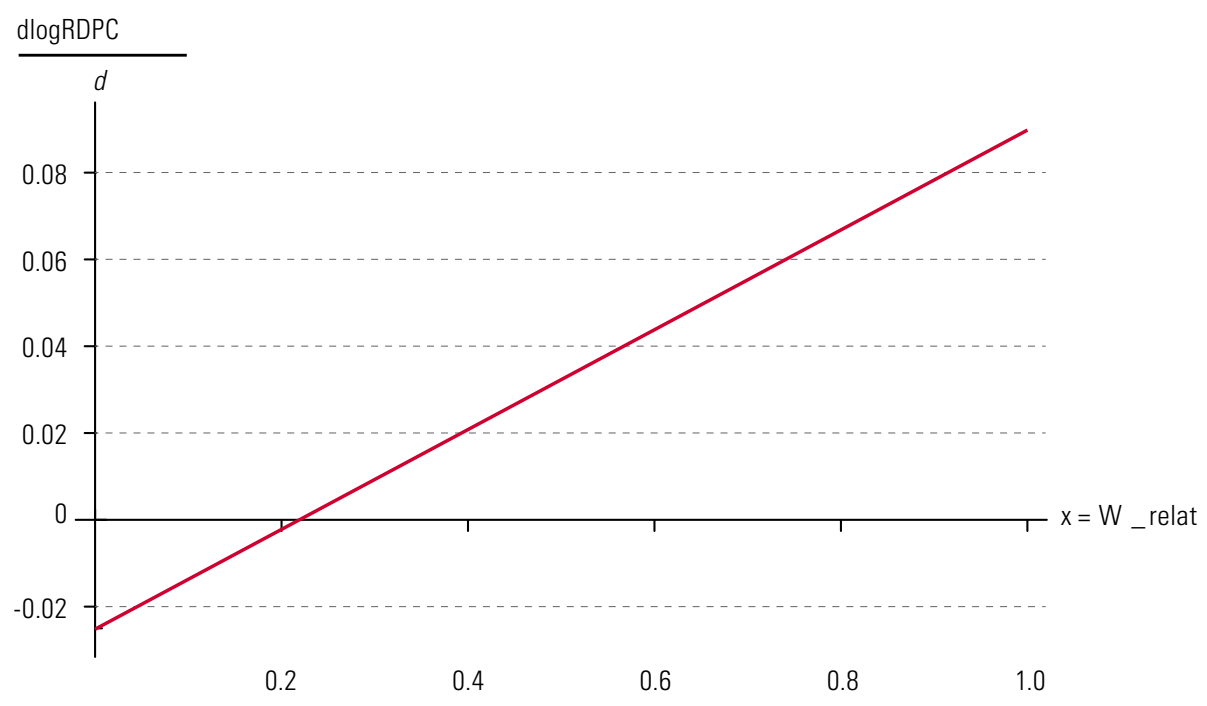

Source: Prepared by the authors.

Note: Simulation based on the results of table 6, column (1).

Table 7 presents the results according to the instrumental variables method and the generalized method of moments.

Columns (1) and (3) present the results of the simplified model, which indicate the same conclusion as table 6. The parameter associated with the proportion of employed persons having completed higher education reflects a negative effect (significant at $1 \%$ in the two columns). The parameter associated with the cross-effect is presented as positive, indicating that the final effect of the relationship depends on the wage differences that reflect different opportunity costs among municipalities (parameters significant at 1\%). While the differences in parameters (instrumental variables and generalized method of moments) are relatively small, there are larger discrepancies in F statistics, indicating efficiency gains in the generalized method of moments.

Considering columns (2) and (4), the inclusion of the other variables influences the estimation of the main parameters of the model, so their exclusion results in overestimation. The additional increase in the proportion of employed persons having completed higher education in the municipality with the highest average income of employed persons contributes to an increase in the per capita income of the municipalities of approximately $12.98 \%$ (column (2)) and $15.84 \%$ (column (4)), compared to $20.80 \%$ (column (1)) and $18.77 \%$ (column (3)). On the basis of the results of table 6 , the magnitude of this effect represents an average value of $9.40 \%$ for the same municipality.

The dividing line between the positive and negative effects of the increase in employed persons having completed higher education on per capita income $\left(\frac{\partial \log (R D P C)}{\partial P_{\text {SUPER }}}=\hat{\beta}_{1}+\hat{\beta}_{2} \cdot w_{\text {relat }} \geq 0\right)$ represents different results across the models. Controlling for the endogeneity of regressors, the relative values of the average income of employed persons above $46 \%$ (see table 7) show a positive relationship between the variables. Without taking endogeneity into account (see table 6 ), the magnitude of relative value is $22 \%$, demonstrating a downward bias of almost $50 \%$ with respect to the instrumental variables method and the generalized method of moments. This result is shown in figure 3 , which simulates the relationship between per capita income and the proportion of employed persons with higher education, according to different relative values of income across municipalities. 
Table 7

Results of the econometric model according to the instrumental variables method and the generalized method of moments

\begin{tabular}{|c|c|c|c|c|}
\hline Variables & $\begin{array}{l}\text { (1) } \\
\text { Instrumental } \\
\text { variables } \\
\text { Fixed effects } \\
\end{array}$ & $\begin{array}{l}\text { (2) } \\
\text { Instrumental } \\
\text { variables } \\
\text { Fixed effects } \\
\end{array}$ & $\begin{array}{l}\text { (3) } \\
\text { Generalized method } \\
\text { of moments } \\
\text { Fixed effects }\end{array}$ & $\begin{array}{l}\text { (4) } \\
\text { Generalized method } \\
\text { of moments } \\
\text { Fixed effects } \\
\end{array}$ \\
\hline \multirow[t]{2}{*}{ PSUPER } & $-0.177^{\star \star \star}$ & $-0.138^{* \star *}$ & $-0.168^{\star \star \star}$ & $-0.125^{\star \star \star}$ \\
\hline & $(0.0244)$ & $(0.0161)$ & $(0.0235)$ & $(0.0144)$ \\
\hline \multirow[t]{2}{*}{$P_{\text {SUPER }}{ }^{*} W_{\text {relat }}$} & $0.366^{\star \star \star}$ & $0.260^{\star \star \star}$ & $0.340^{\star \star \star}$ & $0.272^{\star \star \star}$ \\
\hline & $(0.0437)$ & $(0.0403)$ & $(0.0359)$ & $(0.0387)$ \\
\hline \multirow{2}{*}{$\mathrm{P}_{\text {TRANSF }}$} & & $0.00403^{\star \star \star}$ & & $0.00503^{\star \star \star}$ \\
\hline & & (0.00130) & & $(0.000860)$ \\
\hline \multirow[t]{2}{*}{$\mathrm{REN}_{0}$} & & $-0.00613^{\star \star \star}$ & & $-0.00658^{\star \star *}$ \\
\hline & & $(0.00105)$ & & $(0.000852)$ \\
\hline \multirow[t]{2}{*}{$\mathrm{E}_{\text {ANOSESTUDO }}$} & & $0.0717^{\star \star \star}$ & & $0.0747^{\star \star \star}$ \\
\hline & & $(0.0121)$ & & $(0.0104)$ \\
\hline \multirow[t]{2}{*}{$\mathrm{T}_{\text {MED18M }}$} & & $0.00528^{\star \star \star}$ & & $0.00539^{\star \star \star}$ \\
\hline & & $(0.00170)$ & & $(0.00152)$ \\
\hline \multirow[t]{2}{*}{$\mathrm{T}_{\text {FBMED }}$} & & $9.81 e-05$ & & -0.000242 \\
\hline & & $(0.000439)$ & & $(0.000370)$ \\
\hline \multirow{2}{*}{$\mathrm{T}_{\text {SUPER25M }}$} & & -0.00624 & & -0.0280 \\
\hline & & $(0.0224)$ & & $(0.0186)$ \\
\hline \multirow[t]{2}{*}{ Constant } & $6.134^{\star * \star}$ & $5.508^{* \star \star}$ & $6.190^{\star \star *}$ & $5.487^{\star \star \star}$ \\
\hline & $(0.118)$ & $(0.155)$ & $(0.0992)$ & $(0.133)$ \\
\hline Fixed effects & - & - & - & - \\
\hline - Status & Yes & Yes & Yes & Yes \\
\hline Heteroscedasticity test & - & - & - & - \\
\hline$-\chi^{2}$ & 212.550 & 75.498 & 212.550 & 75.498 \\
\hline - $p$ value & 0.0000 & 0.0000 & 0.0000 & 0.0000 \\
\hline F statistic & 52.97 & 89.57 & 82.30 & 104.3 \\
\hline F statistic ( $p$ value) & 0.0000 & 0.0000 & 0.0000 & 0.0000 \\
\hline LM Kleibergen-Paap statistic $\left(\chi^{2}\right)$ & 14.02 & 16.87 & 14.02 & 16.87 \\
\hline LM Kleibergen-Paap statistic $\left(\chi^{2}\right)$ & 0.00288 & 0.000751 & 0.00288 & 0.000751 \\
\hline Hansen's J-statistic $\left(\chi^{2}\right)$ & 2.015 & 3.056 & 2.015 & 3.056 \\
\hline Hansen's J-statistic ( $p$ value) & 0.365 & 0.217 & 0.365 & 0.217 \\
\hline
\end{tabular}

Source: Prepared by the authors.

Note: $\quad{ }^{* * *} p<0.01,{ }^{* *} p<0.05,{ }^{*} p<0.1$

Confirmation in heteroscedasticity tests involved recalculating the covariance of parameters following the residual series technique using the states as a group model (clusters).

The gross secondary education attendance rate and percentage of the population aged 25 years and over having completed tertiary education showed negative signs and lacked statistical significance, contrary to the results in table 6. The impact of the expectation of years of study on per capita income accumulation nearly doubled when controlling for relative endogeneity problems in the model (0.0717 and 0.0747 in columns (2) and (4) of table 7, respectively, compared to 0.0316 in column (2) of table 6), parameters significant at $1 \%$.

Heteroscedasticity tests revealed a significant presence in all columns (rejection of the null hypothesis at $1 \%)$. This demonstrates the need for the generalized method of moments to increase efficiency.

In all columns of table 7 , instrument validity and relevance tests showed that there was no significant correlation with stochastic disturbance (high $p$ value in Hansen's $\mathrm{J}$ tests), and that there was a strong correlation between the instruments and endogenous regressors. 
Figure 3

Simulation based on the results of the estimated model

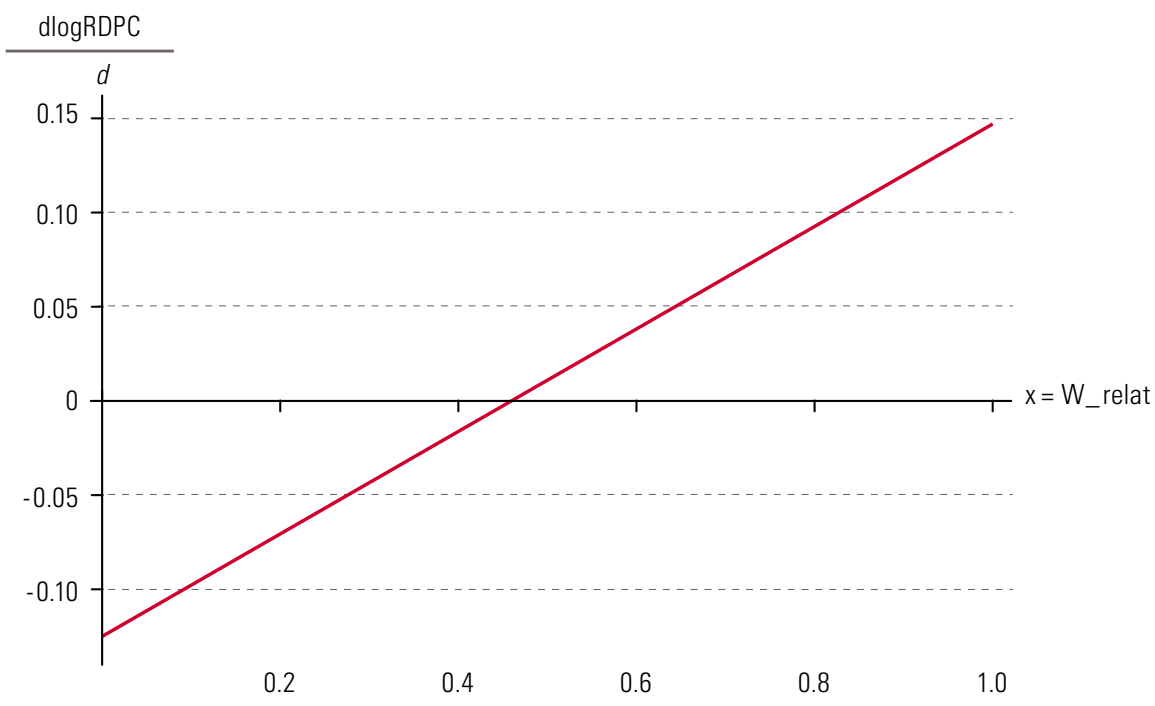

Source: Prepared by the authors.

Note: Simulation based on the results of table 7, column (4).

\section{Analysis of results}

The results indicate that the increase in the proportion of employed persons having completed higher education tends to contribute to greater accumulation of per capita income in municipalities where factor opportunity costs are relatively lower. In this case, the most developed municipalities, with higher levels of per capita income and wage income, offer better incentives for a more skilled workforce. This shows that the contribution of human capital to the increase in wealth reflects heterogeneous results, which are conditioned by the different regional realities. Other regional studies have supported these results, including Aghion and others (2009) and Zhang and Zhuang (2011).

In a study on the composition of investment in education in the United States, Aghion and others (2009) found evidence that investment in higher education stimulated stronger growth in states with higher levels of technological development and therefore closer to the technological frontier. In states at the technological frontier, a US\$1,000 increase in per capita investment in higher education research contributes to an average increase of about 0.04 percentage points in the growth rate. The final result of the investment depends on the coefficient of proximity to the frontier, generating positive or even negative results for the states further from the frontier.

Zhang and Zhuang (2011) assessed the effects of human capital composition on China's growth, distinguishing three education levels: tertiary, secondary and primary. According to the authors, human capital composition plays an important role in regional growth and is influenced by development disparities within the country. The benefits of labour with tertiary level education are greater in the more developed provinces than in the less developed ones. As a result, tertiary education had a positive and significant effect on growth in the more developed provinces, unlike primary and secondary education, for which results were not significant or negative. In this regard, while higher education in China has been responsible for significant progress in economic growth, the reduction of regional disparities is conditioned by investment at all levels, especially in the improvement of primary and secondary education.

Other studies indicate similar results. These include the contributions from Vandenbussche, Aghion and Meghir (2006), Aghion (2008), Ang, Madsen and Islam (2011), Ott and Soretz (2011), Basu and Mehra (2014) and Madsen (2014). 
Gennaioli and others (2013) studied the impact of human capital on development in a sample of over 1,500 regions in 110 countries around the world. The sample covered $74 \%$ of the earth's surface and represented $97 \%$ of global GDP. The results of the study indicated that regional disparities are largely influenced by differences in human capital, but that these differences are more susceptible to different types and levels of education. These differences are reflected in quality and are determined by the composition (quality) of human capital.

From this perspective, countries need a specific type of highly qualified human capital to sustain economic convergence, so that this process can be accelerated in countries where the participation of high-performing students in schools and universities is significant. These advances depend on policies that internalize different compositions in the allocation of resources, which are designed to boost education indicators at different levels (Hanushek and Woessmann, 2012; Ang, Madsen and Islam, 2014).

While this composition is clearly reflected in the different growth rates across the countries, some important aspects such as labour migration can be explained by fluctuations in proximity to the frontier. According to Di Maria and Lazarova (2012), many studies on migration highlight its effects on the level of human capital accumulated, but do not take into account its influence on the composition of human capital. This derives from differences between wages and the employability of the labour force, which affect incentives and are conditioned by the degree of technological development. Economies at the technological frontier have a significant influence on the economic rationality of talent migrating from developing economies. This effect of distribution of highly skilled human capital across different economies has a clear impact on the levels and composition of human capital, reducing the rate of productivity growth in the countries and regions of origin and increasing it in the destination economies (Di Maria and Stryszowski, 2009).

These results may explain how the expansion of skilled labour in the least developed regions contributes proportionally less to income accumulation. This indicates the absence of institutional restrictions on labour migration between municipalities and states, contrary to the regulation observed between countries (Hendricks, 2002).

In this vein, Korpi and Clark (2015) analysed data from a sample of 982,179 persons, including 126,233 internal migrants, in microdata from Sweden. ${ }^{6}$ The results indicated that the most skilled workers captured the largest share of the significant income increases as they migrated to the most developed metropolises. This suggests that human capital reflects a selective pattern in internal migration between regions, attributing different weights in composition according to different income distributions.

\section{Limitations of the study and suggestions for future research}

Although the results of the empirical exercise align with the assumptions presented in the theoretical model, it is necessary to properly outline some important aspects highlighted in the study.

In the Brazilian labour market, the public sector exerts a notable influence, increasing the skill premium of the labour force and competing with major segments of the private sector, especially in lower income municipalities. This made it possible to partly sustain the expansion of the welfare state through public employment (Mattos, 2015 and 2011). In addition, some inconsistencies in the concept of workers' skills associated with the level of schooling in Brazil have given rise to differences in many empirical tests, indicating new ways of perceiving workers' skills. This is because some important results indicate the absorption of skilled workers in occupations requiring a lower level of education. Data from the National

\footnotetext{
6 Statistics Sweden's Microdata Online Access (MONA) database [online] https://www.scb.se/en/services/guidance-for-researchersand-universities/mona--a-system-for-delivering-microdata/.
} 
Household Sample Survey (PNAD) from 1981 to 2001 indicate a trend towards the increasing precarity of skills associated with the underutilization of workers with higher education levels in Brazil. In this case, a possible surplus of highly skilled workers ends up being "forced" into activities that require lower skill levels, possibly owing to the lack of options in the labour market (Machado, Oliveira and Carvalho, 2004).

However, some recent research indicates that the average wage ratio of workers having completed secondary education has varied between 2.65 and 2.9 times since the 2000s, indicating a considerable increase in the demand for higher education over the period (Insper, 2016; Rocha and others, 2017). Some estimates made from 2000 to 2010 at the municipal level indicate that a 1 percentage point change in the proportion of adults with higher education is associated with a 0.4 percentage point increase in the employment rate and growth of $0.9 \%$ in wages and $1.3 \%$ in household per capita income (Rocha and others, 2017, p. 66).

Although these results are consistent with the economic realities of different periods, no peaceful consensus has been reached on the impact of human capital on Brazil's development. "Peaceful consensus" is highlighted here, based on heterogeneous results which must be refined in future research to more accurately capture possible divergence between demand and supply in the labour market and the consequences for growth in Brazilian municipalities.

This research indicates, in the theoretical model, the existence of different activities that require differentiated production factors. From a Schumpeterian perspective, different activities require factors that complement the prevailing technological model. Consequently, it is not reasonable to treat different employment categories with a single measure, as is clear from relevant national research (Machado, Oliveira and Carvalho, 2004; Insper, 2016; Rocha and others, 2017) and international research (Ang, Madsen and Islam, 2011; Ott and Soretz, 2011; Basu and Mehra, 2014; Madsen, 2014).

Also, regression analysis and other techniques based on the average of the conditional distribution of the model may not capture these imperfections in the labour market, over- or underestimating the relationships between variables. In the technique proposed in this study, the differences in income between the municipalities are adopted to capture possible differences in demand across the regions. These differences can significantly influence the impact of workers with higher education on the per capita income of municipalities. Furthermore, if there are no controls for endogeneity, the estimated parameters may reflect erroneous relationships that should be interpreted with due caution (Imbens, 2014; Fan and Liao, 2014; Ackerberg and others, 2014; Lenkei, Mustafa and Vecchi, 2018; Chaudhuri and Guilkey, 2016).

In addition to these highlighted issues, the problems arising from the use of an aggregate database should be underscored. In this case, depending on the level of aggregation, much information about the variables can "smooth out" the relationships in the model, potentially limiting the results. However, the above-mentioned potential costs are minimized to the extent that the theoretical model set forth differentiates the empirical exercise from the studies presented. While not avoiding the relevance of such restrictions, we emphasize that the alternative approach proposed here mitigates their costs, and the results are consistent with international research such as that of Vandenbussche, Aghion and Meghir (2006), Ang, Madsen and Islam (2011), Basu and Mehra (2014) and Madsen (2014).

\section{Concluding remarks}

This study analysed the contribution of the increase in workers with higher education to per capita income in Brazilian municipalities, to the extent that the different incomes among employed persons affects the magnitude of this contribution. Using a Schumpeterian growth model based on the approaches of Aghion and Howitt (2009 and 1998), the decision of the monopolistic firm to maximize its profits depends on two components of human capital: (i) highly skilled workers engaged in innovation activities and (ii) low-skilled workers carrying out imitation and technology transfer activities. 
Under optimized conditions, companies' demand for low-skilled labour depends positively on the degree of proximity to the technological frontier. Based on the results of the model, final demand for low-skilled workers is greatest among the companies furthest from the technological leader (frontier) of the sector. As companies move closer to the technological frontier, total demand reflects a larger share of workers dedicated to innovation activities and, therefore, with higher skill levels. In wage differences among factors, the distance from the frontier increases the opportunity costs of skilled labour reducing the skill premium, as the results of the empirical model suggest.

The empirical results based on municipal data from the 2010 census indicate that the contribution of the increase in employed persons with higher education tends to be greater in municipalities with smaller income differences compared to the highest value recorded in each state. The increase in income differences raises factor opportunity costs, contributing to a possible migration effect in higher income regions. The results also suggest that municipalities with low per capita income offer fewer opportunities and therefore fewer benefits associated with curbed demand.

Municipalities with incomes above $46 \%$ of the maximum income recorded in the state reflect a positive relationship between the increase in employed persons with higher education and per capita income. These results indicate that the final effect of the expansion of the skilled labour force in the country depends on significant labour market characteristics that increase the demand for the skills acquired through higher education. The neglect of public policies targeting both supply (higher education training) and demand (employment in income-generating activities for this type of factor) may contribute to the increase in regional inequalities.

While these results indicate better coordination of policies (especially education and industrial), the limitations of the study point to future lines of research: different types of higher education training, quality of training, differences between public and private education, and differences between investments by level (primary, secondary and higher), among other relevant factors that were not included in the scope of this research.

Furthermore, the adherence of empirical results to the theoretical model requires an interpretation that has yet to be made, with due caution. In this case, part of the increase in income in municipalities may be influenced by activities that employ skilled workers when, in fact, less skilled workers are needed. Therefore, this study indicates the need for different types of human capital for different activities, which may have an impact on differentiated growth patterns across economies.

While this differentiated growth across economies may explain some of the inequalities, further research is needed, especially in the different labour markets, to understand how and what types of human resources are most needed based on municipalities' characteristics. Finally, the results presented indicate that the concept of human capital, based on aggregate metrics, may limit the way in which education contributes to development.

\section{Bibliography}

Acemoglu, D. (1998), "Why do new technologies complement skills? Directed technical change and wage inequality", The Quarterly Journal of Economics, vol. 113, No. 4, November.

Acemoglu, D., F. Gallego and J. Robinson (2014), "Institutions, human capital and development", Annual Review of Economics, vol. 6.

Acharya, V., R. Baghai and K. Subramanian (2014), "Wrongful discharge laws and innovation", The Review of Financial Studies, vol. 27, No. 1, January.

Ackerberg, D. and others (2014), "Asymptotic efficiency of semiparametric two-step GMM", The Review of Economic Studies, vol. 81, No. 3, July.

Aghion, P. (2008), "Higher education and innovation", Perspektiven der Wirtschaftspolitik, vol. 9, No. S1, May. 
Aghion, P. and P. Howitt (2009), The Economics of Growth, Cambridge, The MIT Press. (1998), Endogenous Growth Theory, Cambridge, The MIT Press.

Aghion, P. and others (2009), "The causal impact of education on economic growth: evidence from the United States", Brookings Papers on Economic Activity, spring, Washington, D.C., Brookings Institution Press.

Ang, J., J. Madsen and M. Islam (2014), "Quality-adjusted human capital and productivity growth", Economic Inquiry, vol. 52, No. 2, April.

(2011), "The effects of human capital composition on technological convergence", Journal of Macroeconomics, vol. 33, No. 3.

Barro, R. (2001), "Human capital and growth", The American Economic Review, vol. 91, No. 2.

Barro, R. and X. Sala-i-Martin (1992), "Convergence", Journal of Political Economy, vol. 100, No. 2.

Bastgen, A. and C. Holzner (2017), "Employment protection and the market for innovations", Labour Economics, vol. 46, June.

Basu, S. and M. Mehra (2014), "Endogenous human capital formation, distance to frontier and growth", Research in Economics, vol. 68, No. 2, June.

Baum, C., M. Schaffer and S. Stillman (2003), "Instrumental variables and GMM: estimation and testing", The Stata Journal, vol. 3, No. 1, Texas, Stata Corporation.

Becker, S., E. Hornung and L. Woessmann (2011), "Education and catch-up in the industrial revolution", American Economic Journal: Macroeconomics, vol. 3, No. 3, July.

Becker, S. and L. Woessmann (2009), "Was Weber wrong? A human capital theory of protestant economic history", The Quarterly Journal of Economics, vol. 124, No. 2, May.

Benhabib, J. and M. Spiegel (2005), "Human capital and technology diffusion", Handbook of Economic Growth, vol. 1A, P. Aghion and S. Durlauf (eds.), Amsterdam, North-Holland.

(1994), "The role of human capital in economic development: evidence from aggregate cross-country data", Journal of Monetary Economics, vol. 34, No. 2, October.

Bond, S., A. Hoeffler and J. Temple (2001), "GMM estimation of empirical growth models", Economics Discussion Papers, No. 2001-W21, Oxford, University of Oxford.

Cameron, A. and P. Trivedi (2005), Microeconometrics: Methods and Applications, New York, Cambridge University Press.

Caselli, F. and W. Coleman (2006), "The world technology frontier", The American Economic Review, vol. 96, No. 3, June.

Chaudhuri, S. and D. Guilkey (2016), "GMM with multiple missing variables", Journal of Applied Econometrics, vol. 31, No. 4.

Costa, D., A. Costa and F. Barbosa (2013), "Financiamento público e expansão da educação superior federal no Brasil: o REUNI e as perspectivas para o REUNI 2", Revista Gestão Universitária na América Latina, vol. 6, No. 1, January.

Cury, C. (2014), "Formação e conhecimento: perspectivas filosóficas e sociológicas", Avaliação: Revista da Avaliação da Educação Superior, vol. 19, No. 3.

Di Maria, C. and E. Lazarova (2012), "Migration, human capital formation, and growth: an empirical investigation", World Development, vol. 40, No. 5, May.

Di Maria, C. and P. Stryszowski (2009), "Migration, human capital accumulation and economic development", Journal of Development Economics, vol. 90, No. 2, November.

Dosi, G., G. Fagiolo and A. Roventini (2010), "Schumpeter meeting Keynes: a policy-friendly model of endogenous growth and business cycles", Journal of Economic Dynamics and Control, vol. 34, No. 9.

Durlauf, S., P. Johnson and J. Temple (2005), "Growth econometrics", Handbook of Economic Growth, vol. 1A, P. Aghion and S. Durlauf (eds.), Amsterdam, North-Holland.

Fan, J. and Y. Liao (2014), "Endogeneity in high dimensions", The Annals of Statistics, vol. 42, No. 3, June.

Felicetti, V., A. Cabrera and M. Costa-Morosini (2014), "Aluno ProUni: impacto na institução de educação superior e na sociedade", Revista Iberoamericana de Educación Superior, vol. 5, No. 13.

Galvao, A. and G. Montes-Rojas (2015), "On the equivalence of instrumental variables estimators for linear models", Economics Letters, vol. 134, September.

Gennaioli, N. and others (2013), "Human capital and regional development", The Quarterly Journal of Economics, vol. 128, No. 1, Oxford, Oxford University Press.

Greene, W. (2012), Econometric Analysis, 7th Edition, Boston, Prentice Hall.

Hansen, L. (1982), "Large sample properties of generalized method of moments estimators", Econometrica, vol. 50, No. 4, July. 
Hanushek, E. and L. Woessmann (2012), "Do better schools lead to more growth? Cognitive skills, economic outcomes, and causation", Journal of Economic Growth, vol. 17, No. 4, December.

Hayashi, F. (2000), Econometrics, Princeton, Princeton University Press.

Hendricks, L. (2002), "How important is human capital for development? Evidence from immigrant earnings", The American Economic Review, vol. 92, No. 1, March.

Hsiao, C. and J. Zhang (2015), "IV, GMM or likelihood approach to estimate dynamic panel models when either N or T or both are large", Journal of Econometrics, vol. 187, No. 1, July.

IBGE (Brazilian Institute of Geography and Statistics) (n/da), "Censo demográfico" [online] https://www.ibge. gov.br/estatisticas/sociais/populacao/9662-censo-demografico-2010.html?edicao=9673\&t=downloads. (n/db), "Pesquisa Nacional por Amostra de Domicilios - PNAD" [online] https://www.ibge.gov.br/estatisticas/ sociais/populacao/9127-pesquisa-nacional-por-amostra-de-domicilios.html?=\&t=downloads.

Imbens, G. (2014), "Instrumental variables: an econometrician's perspective", Statistical Science, vol. 29, No. 3, August.

INEP (National Institute for Educational Studies and Research Anísio Teixeira) (2016), "Sinopse Estatística da Educação Superior 2015" [online database] http://portal.inep.gov.br/web/guest/sinopses-estatisticasda-educacao-superior.

Insper (2016), "Panorama do mercado de trabalho" [online] https://www.insper.edu.br/wp-content/ uploads/2018/09/Panorama-do-Mercado-de-Trabalho-CPP-2016.pdf.

Kleibergen, F. and R. Paap (2006), "Generalized reduced rank tests using the singular value decomposition", Journal of Econometrics, vol. 133, No. 1.

Koeniger, W. (2005), "Dismissal costs and innovation", Economics Letters, vol. 88, No. 1, July.

Korpi, M. and W. Clark (2015), "Internal migration and human capital theory: to what extent is it selective?", Economics Letters, vol. 136, November.

Lenkei, B., G. Mustafa and M. Vecchi (2018), "Growth in emerging economies: is there a role for education?", Economic Modelling, vol. 73, June.

Lima, K. (2012), "Expansão e reestruturação das universidades federais e intensificação do trabalho docente: o Programa REUNI", Revista de Políticas Públicas, vol. 16, October.

Lucas, R. (2009), "Ideas and growth", Economica, vol. 76, No. 301, February.

Machado, A., A. Oliveira and N. Carvalho (2004), "Tipologia de qualificação da força de trabalho: uma proposta a partir da noção de incompatibilidade entre ocupação e escolaridade", Nova Economia, vol. 14, No. 2.

Madsen, J. (2014), "Human capital and the world technology frontier", The Review of Economics and Statistics, vol. 96, No. 4, October.

Mancebo, D., A. Vale and T. Martins (2015), "Políticas de expansão da educação superior no Brasil 1995-2010", Revista Brasileira de Educação, vol. 20, No. 60.

Mattos, F. (2015), "Trajetória do emprego público no Brasil desde o início do século XX", Ensaios FEE, vol. 36, No. 1, Porto Alegre, Foundation for Economics and Statistics.

(2011), "Emprego público nos países desenvolvidos: evolução histórica e diferenças nos perfis", Texto para Discussão, No. 1578, Brasilia, Institute of Applied Economic Research (IPEA).

Ott, I. and S. Soretz (2011), "Public policies and convergence", Journal of Economic Dynamics and Control, vol. 35, No. 9.

Philippon, T. and A. Reshef (2012), "Wages and human capital in the U.S. finance industry: 1909-2006", The Quarterly Journal of Economics, vol. 127, No. 4, November.

Rocha, R. and others (2017), "A relação entre o ensino superior público e privado e a renda e emprego nos municípios brasileiros", Pesquisa e Planejamento Econômico, vol. 47, No. 3, December.

Schiopu, I. (2015), "Technology adoption, human capital formation and income differences", Journal of Macroeconomics, vol. 45, September.

UNDP/IPEA/FJP (United Nations Development Programme/Institute of Applied Economic Research/João Pinheiro Foundation) (2013), "Atlas of Human Development in Brazil" [online database] http://www. atlasbrasil.org.br/2013/en/consulta/.

Vandenbussche, J., P. Aghion and C. Meghir (2006), "Growth, distance to frontier and composition of human capital", Journal of Economic Growth, vol. 11, No. 2, June.

Zhang, C. and L. Zhuang (2011), "The composition of human capital and economic growth: evidence from China using dynamic panel data analysis", China Economic Review, vol. 22, No. 1, March. 